\title{
POTENTIAL YIELD OF ACID-ADAPTIVE SOYBEAN PROMISING LINES IN ULTISOLS OF TANAH LAUT REGENCY, SOUTH KALIMANTAN PROVINCE, INDONESIA
}

\author{
HERU KUSWANTORO \\ Indonesian Leejumeand Tuber Crops Reserrch Institute- \\ IndonesianAgny for Agiailtural Reserch andDedopmet, Malang65101, Indonesia
}

Received 20 November 2015/ Accepted 26 May 2016

\begin{abstract}
Soybean is an important food commodity after rice and com in Indonesia. Until now soybean demand cannot be fulfilled by domestic production, although the chances of fulfillment can be attempted. O ne of the attempts to increase domestic production is soybean planting in acid dry land that is widely available in Indonesia. The research aimed to obtain soybean lines that are adaptive in acid dry land. A total of 10 soybean promising lines and two check varieties (Wilis and Tanggamus) were grown in acid dry land in Tanah Laut Regency, South Kalimantan Province, Indonesia. Experimental design used was randomized complete block design with four replications. The data were analyzed using analysis of variance and followed by Least Significant Different test. The results showed that the promising lines of SC5P2P3.5.4.1-5 and SC5P2P3.23.4.1-5 achieved production of 1.51 t/ ha and 1.48 t/ha, respectively. These yields were higher than Wilis and Tanggamus varieties that reached $1.41 \mathrm{t} /$ ha and $1.13 \mathrm{t} / \mathrm{ha}$, respectively. These two promising lines had the potency to be developed in Tanah Laut Regency, South Kalimantan or otherareas with similar soil characteristics.
\end{abstract}

Keywords: Acid dryland, soybean, Tanah Laut Regency, ultisols

\section{INTRODUCTION}

Soybean is an important food crops for Indonesia and is ranked third after rice and corn. Soybean self-sufficiency in 2017, announced by the Indonesian Government, needs to be followed up with efforts in the area of soybean planting in accordance with soybean growth requirements. Soybean has the ability to grow in areas with optimal up to suboptimal soil types. Soybean can be planted in all soil types such as Grumusols, Inceptisol, Ultisols and others. Therefore, various efforts have been and are being carried out for soybean planting in various agroecology such as paddy fields, dry land, acid dry land and tidal swamp land.

O pportunity of soybean development in acid dry land is very high, not only because of soybean ability to grow in acid dry land, but also because of the wide area of acid dry land. A cidic dry land area

\footnotetext{
*Corresponding author: herukusw@ yahoo.com
}

in Indonesia is 108.8 million ha or approximately $69.4 \%$ of the total dry land in Indonesia (BBSD LP 2012). Dry land with Ultisols and Oxisols soil types occupy the largest area in Indonesia (Hidayat \& Mulyani 2002). Acidic dry land area in South Kalimantan Province is 2,189,535 ha (Mulyani \& Syarwani 2013). Ultisols soil type located in South Kalimantan Province is included in soil suborder of Udults, namely Ultisols that develops in areas with udic moisture regime(Nugroho \& Istianto 2009).

Soybean ability to adapt in Ultisols soil types can be reflected on soybean improvement efforts through plant breeding programs as well as the amelioration of the land that suitable for soybeans growth requirements. Usually, soybean improvement for acid dry land adaptation in breeding program is conducted by crossing, followed by the selection of segregating populations, yield trials and adaptation trials. Adaptation trial should be conducted in the target area in order to obtain the soybean promising 
lines that can adapt in this area. In this study, the target area was acid dry land in Tanah Laut Regency, South Kalimantan Province having Ultisols soil type. The research aimed to obtain soybean lines that are adaptivein acid dryland.

\section{MATERIALS AND METHODS}

\section{Study Site}

The study was carried out in Tanah Laut Regency, South Kalimantan Province $\left(3^{\circ} 41^{\prime} 31.9^{\prime \prime}\right.$ S; $114^{\circ} 44^{\prime} 00.8^{\prime \prime} \mathrm{E}$ ) having Ultisols soil type with soil $\mathrm{pH}\left(\mathrm{H}_{2} \mathrm{O}\right)$ of 5.5; Exchangeable $\mathrm{Al}$ and $\mathrm{H}$ of $0.67 \mathrm{me} .100 / \mathrm{g}$ and $1.53 \mathrm{me} .100 / \mathrm{g}$, respectively. O ther soil properties are shown in Table 1.

\section{Plant Materials}

Ten promising lines of SC2P2.99.5.4.5-1-6-1 (G1), SC2P2.151.3.5.1-10 (G 2), SC5P2P3.5.4.1-5 (G 3), SC 5P 2P 3.23.4.1-3-28-3 (G 4), SC5P2P3.23.4.1-5 (G5), SC5P2P3.48.31.1-10 (G6), SJ-5/ Msr.99.5.4.5-1-6-1 (G 7), Msr/ SJ5.21.3.7-3-27-1 (G 8), Msr/ SJ-5.23.4.1-3-28-3 (G9) and Msr/ SJ-5.23.4.1-5(G10) and two check varieties Tanggamus (G11) and Wilis (G12) were used in this experiment. The ten promising lines were derived from crossing of Mansuria and SJ-5 genotypes. Tanggamus is an acid-adaptive soybean variety, while Wilis is a broadly-adaptive soybean variety.

\section{Soil Preparation}

To obtain optimal soil structure condition for ideal growth of the soybean, soil tillage was carried out by plowing the soil twice until $20 \mathrm{~cm}$ depth and then flatting by harrowing the soil. $D$ rainage canals were made every $4.5 \mathrm{~m}$ to prevent water logging in case of hard rainfall.

\section{Design and Planting}

The experimental design applied was randomized completely block design with four replications. Plot size was $2.8 \times 4.5 \mathrm{~m}$ and plant spacing of $40 \times 15 \mathrm{~cm}$ with two plants per hill. Fertilizers applied were $75 \mathrm{~kg}$ urea, $125 \mathrm{~kg}$ SP36 and $75 \mathrm{~kg} \mathrm{KCl}$ per ha, which were spread before planting. Control of weeds, pests and diseases were performed optimally by monitoring scheme.

\section{O bservation and Data Analysis}

O bservations were conducted on days to $50 \%$ flowering (then stated as days to flowering) and days to $95 \%$ maturing (then stated as days to maturing), plant height, number of reproductive nodes per plant, number of filled and unfilled pods per plant, 100 grains weight and grain yield. D ata were analyzed using analysis of variance (ANOVA) and followed by Least Significant D ifferencetest (LSD) at $\alpha=0.05$.

Table 1 Soil properties

\begin{tabular}{lc}
\hline Soil properties & Value \\
\hline $\mathrm{pH}\left(\mathrm{H}_{2} \mathrm{O}\right)$ & 5.05 \\
$\mathrm{pH}(\mathrm{KCl})$ & 4.15 \\
$\mathrm{~N}(\%)$ & 0.13 \\
$\mathrm{CO}(\mathrm{ppm})$ & 1.48 \\
$\mathrm{P}_{2} \mathrm{O}_{5}(\mathrm{ppm})$ & 8.08 \\
$\mathrm{SO}_{4}(\mathrm{ppm})$ & 42.30 \\
$\mathrm{Fe}(\mathrm{ppm})$ & 48.90 \\
$\mathrm{Mn}(\mathrm{ppm})$ & 245.00 \\
$\mathrm{Cu}(\mathrm{ppm})$ & 6.13 \\
$\mathrm{Zn}(\mathrm{ppm})$ & 4.20 \\
$\mathrm{~K}(\mathrm{ppm})$ & 0.48 \\
$\mathrm{Na}(\mathrm{me} / 100 \mathrm{~g})$ & 0.21 \\
$\mathrm{Ca}(\mathrm{me} / 100 \mathrm{~g})$ & 5.11 \\
$\mathrm{Mg}(\mathrm{me} / 100 \mathrm{~g})$ & 2.06 \\
$\mathrm{KTK}(\mathrm{me} / 100 \mathrm{~g})$ & 34.00 \\
$\mathrm{Aldd}(\mathrm{me} / 100 \mathrm{~g})$ & 0.67 \\
$\mathrm{Hdd}(\mathrm{me} / 100 \mathrm{~g})$ & 1.53 \\
\hline
\end{tabular}




\section{RESULTS AND DISCUSSION}

In this study, there were three genotypes having early days to flowering namely SC5P2P3.5.4.1-5, Msr/ SJ-5.23.4.1-3-28-3 and Wilis with days to flowering of 34 days. On the other hand, there were four genotypes having days to flowering of 40 days or higher namely SC5P2P3.23.4.1-5, SC5P2P3.48.31.1-10, SJ5/ Msr.99.5.4.5-1-6-1 and Msr/ SJ-5.23.4.1-5 (Fig. 1). Different days to flowering are affected by the genotypes, where they are affected by genes that repressing (Cao \&al. 2015) or inducing (Na \& al. 2013) as the response to the environmental parameters such as temperature (Lee $\notin \mathrm{al}$. 2005; Xia $\&$ al. 2012), photoperiod and other environmental stimuli (Xia \&al. 2012).

Days to maturing of the tested genotypes varied. Trend of days to maturing is similar to trend of days to flowering. Genotype having longer flowering days also showed longer maturing days and vice versa. However, there is one genotype (Wilis) having early flowering day and longer maturing days. D ays to maturing is important in soybean because different maturing day response to the yield. Soybean is a photoperiod-sensitive and self-pollinated species. D ays to flowering (DTF) and maturing (DTM), duration from flowering-to-maturing (DFTM) and plant height $(\mathrm{PH})$ are crucial for soybean adaptability and yield (Zhang \& al. 2015). Therefore, temperature is related to the maturity of soybean (Kumagaia \& Sameshima 2014).

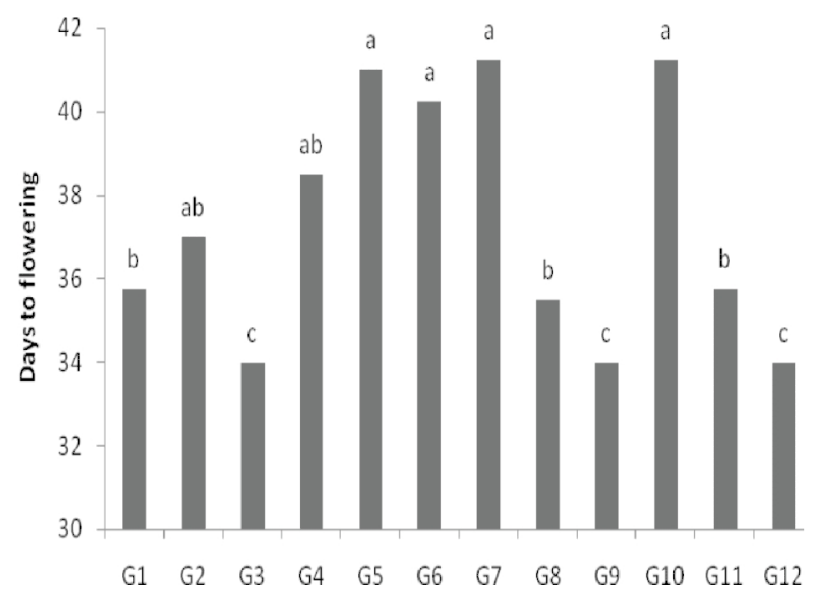

Plant height varied among the tested genotypes. The highest plant height was SC5P2P3.23.4.1-5 and the lowest plant was SC5P2P3.5.4.1-5. The check varieties Tanggamus and Wilis were included as having medium plant height in this study. Plant height is influenced by the genotypes and environment. Genes in the genotypes works to perform plant height supported by the environment. In rainy season soybean plant height is higher than in dry season (Kuswantoro \& Zen 2013). In physiological point of view, plant height is also affected by solar radiation. Z hang $\&$ al. (2014) stated that solar ultraviolet radiation exclusion increases soybean plant height due to the internodes elongation. Plant height has relationship to grain yield as stated by many authors (Lee etal. 2015; Liu 2013).

The lowest number of reproductive nodes was achieved by SC5P2P3.5.4.1-5. The highest number of reproductive nodes was achieved by SC2P2.99.5.4.5-1-6-1, in which SC2P2.99.5.4.51-6-1 was also included as having higher plant height. Number of reproductive nodes had similar pattern to plant height (Fig. 2). Higher plant height leads to higher number of reproductive nodes, because higher plant allows more branches to grow than lower plant. In this case, the length of the main stem is the most important factor for plant height. At the R5 growth stage, nodes development on the main stem and on the branches reach the maximum (Egli \&al. 1985). Number of reproductive nodes is affected by number of branches. Higher branch

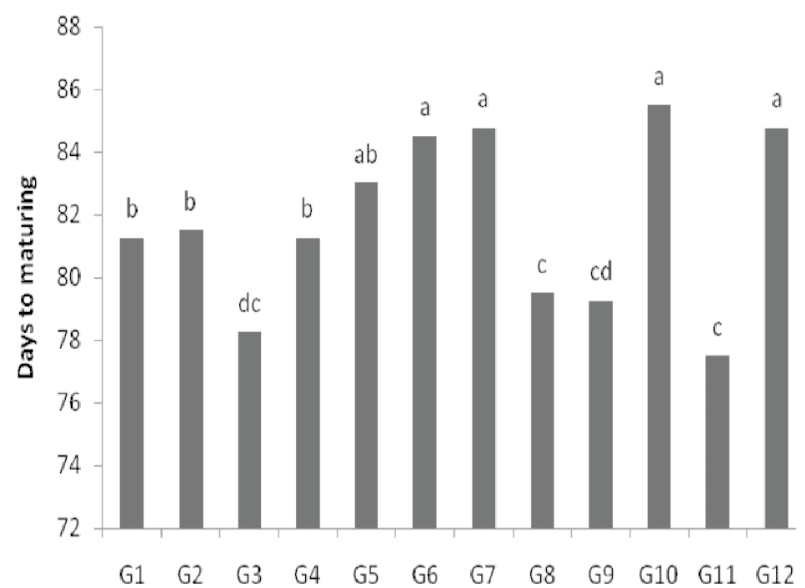

Figure 1 D ays to flowering and days to maturing of acid-adaptive soybean promising lines in Tanah Laut Regency, South Kalimantan Province (rainy season 2012) 

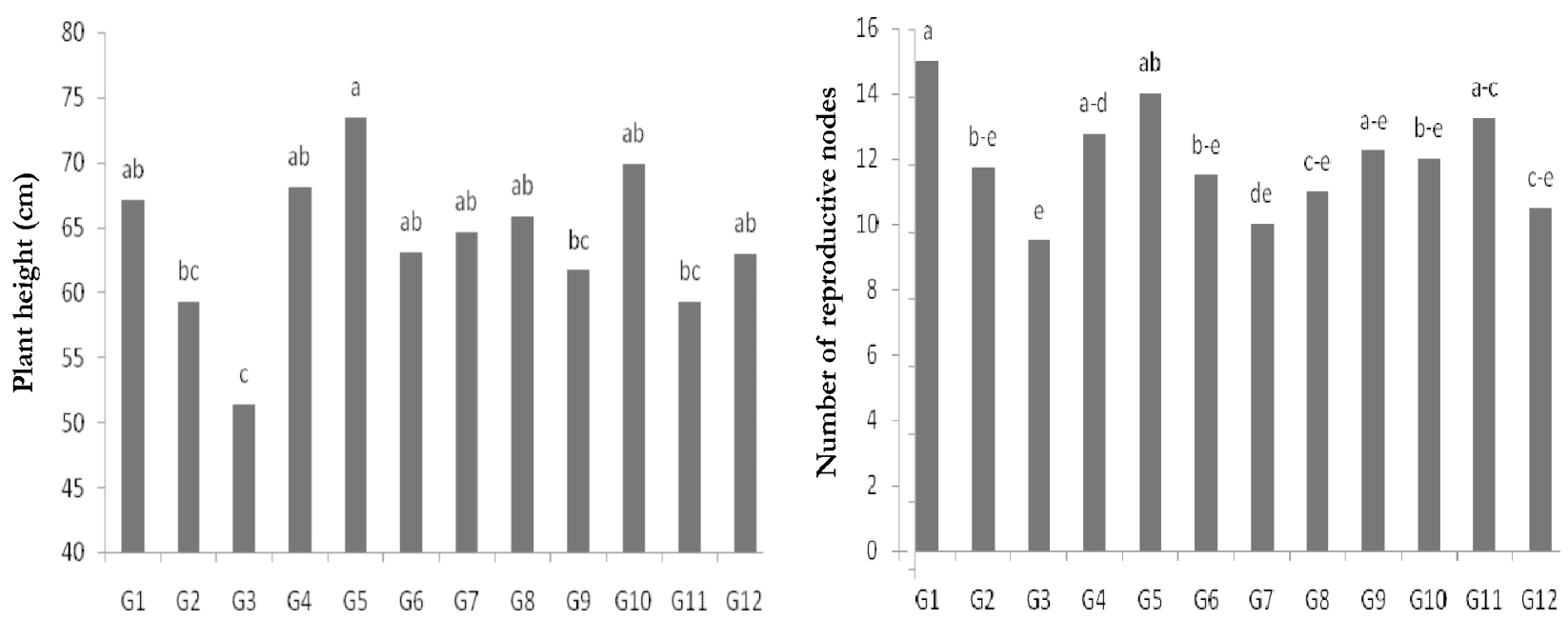

Figure 2 Plant height and number of reproductive nodes of acid-adaptive soybean promising lines in Tanah Laut Regency, South Kalimantan Province (rainy season 2012)

dry matter per plant affecting more branch nodes and branch reproductive nodes indicates that number of branches and number of reproductive nodes have a close relationship (Carpenter \& Board 1997).

The highest number of filled pods was achieved by SC5P2P3.23.4.1-5, Msr/ SJ-5.23.4.13-28-3 and Tanggamus, while the lowest was achieved by SC5P2P 3.5.4.1-5. This indicated that the tested soybean lines varied in pods number trait. Numbers of filled pods in this study were lower than other study with the same soybean lines, although the soil $\mathrm{pH}$ is higher. This phenomenon might be due to the lower water availability (Kuswantoro \& Zen 2013). Low water availability at pod filling period may accelerate senescence and shorten pod filling period (De Sousa đal. 1997).

The pattern of number of filled pods was not similar to the pattern of number of unfilled pods (Fig 3). SC5P2P3.5.4.1-5 had the highest number of unfilled pods and had the lowest number of filled pods. Tanggamus was the soybean variety that achieved the highest number of filled pods and unfilled pods. This difference indicated that there is no relationship between these two characters. Genetic constitution has important role in expressing the number of unfilled pods against environmental effects. It is indicated by the broad-sense heritability of unfilled pods achieving $93.1 \%$ (Sahay \&al. 2005).
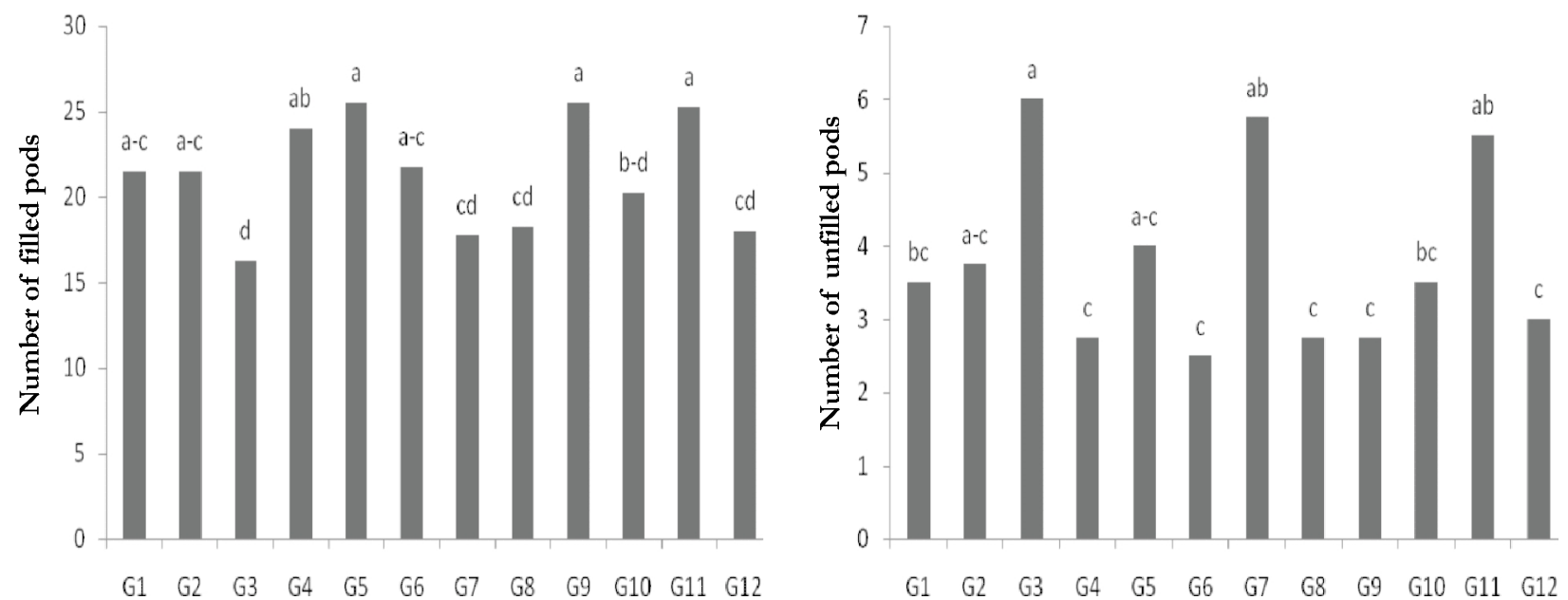

Figure 3 Number of filled pods and number of unfilled pods of acid-adaptive soybean promising lines in Tanah Laut Regency, South Kalimantan Province (rainy season 2012) 

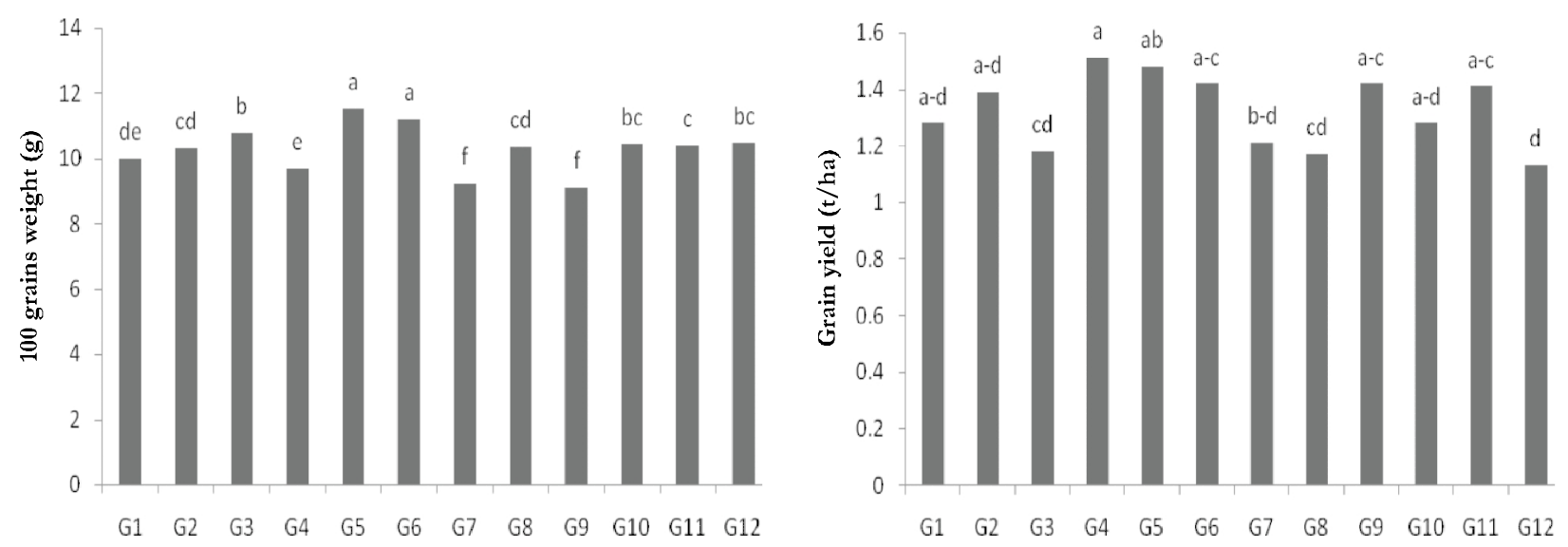

Figure 4 100-grain weight and grain yield of acid-adaptive soybean promising lines in Tanah Laut Regency, South Kalimantan Province (rainy season 2012)

The largest grain size were shown by SC5P2P3.23.4.1-5 and SC5P2P3.48.31.1-10, while the smallest were shown by SJ5/ Msr.99.5.4.5-1-6-1 and Msr/ SJ-5.23.4.1-3-28-3 (Fig. 4). G rain size of the check varieties were in the middle rank of the tested genotypes. G rain size is one of the main components affecting grain yield. Grain size can decrease (Kuswantoro e al. 2014) or increase (Kuswantoro 2015) grain yield through modification of environmental factors such as soil acidity. Therefore, grain size is more affected by environmental factors rather than by genetic constitution (Liu $\&$ al. 2010). This is supported by Hakim \& al. (2014) who found medium heritability with value of $46.3 \%$.

The line of SC5P2P3.23.4.1-3-28-3 achieved production of $1.51 \mathrm{t} /$ ha which was higher than that of Wilis and Tanggamus varieties which reached production of $1.41 \mathrm{t} /$ ha and $1.13 \mathrm{t} / \mathrm{ha}$, respectively. Other line that achieved relatively higher grain yield was SC5P2P3.23.4.1-5 with grain yield of $1.48 \mathrm{t} / \mathrm{ha}$. Tanggamus is the check variety for wide adaptation variety. In this study Wilis had lower grain yield than that of Tanggamus, the soybean check variety for adaptability to acid soil. G rain yield is a complex character and affected by other components. The most important characters in supporting grain yield are grain size and number of grain yield. Some authors reported that there were significant correlation (Malik \& al. 2011) and genetic correlation (A rshad $\notin a l$. 2006) between grain yield and 100 grains weight; and a positive direct effect between 100 grains weight and grain yield (ElBadawy 2012). Similar to number of grain size, some authors also reported the relationship between grain yield and number of pods (Arslan etal. 2005), and positive direct effect with number of pods per plant (Valencia-Ramírez \& LigarretoMoreno 2012).

\section{CONCLUSIONS}

The promising lines of SC5P2P3.5.4.1-5 and SC5P2P3.23.4.1-5 achieved production of $1.51 \mathrm{t} / \mathrm{ha}$ and $1.48 \mathrm{t} / \mathrm{ha}$, respectively, which were higher than the production of Tanggamus and Wilis varieties. The yield of these two promising lines was also supported by number of filled pods. Promising lines of SC5P2P3.5.4.1-5 and SC5P2P3.23.4.1-5 has potency to be developed in Tanah Laut Regency, South Kalimantan or other areas with similar soil characteristics.

\section{ACKNOWLEDGEMENTS}

This study was funded by the Korean Government through Asian Food and Agriculture Cooperation Initiative (AFACI) Project 2012.

\section{REFERENCES}

Arshad M, Ali N, G hafoor A. 2006. Character correlation and path coefficient in soybean Glycine max (L.) Merrill. Pakistan J Bot38:121-30. 
Arslan M, Uremis I, Uludag A. 2005. Effects of weed-free period on seed yield and yield components of double-cropped soybean (Glyoime max L.). Asian J PlantSci4:271-4.

BBSD LP (Balai Besar Litbang Sumberdaya Lahan Pertanian). 2012. Lahan SubOptimal: Potensi, Pduang dan Pemasalahan Pemanfaatannya untuk Mendukung Program Ketahanan Pangan Palembang (ID ): Kementerian Riset dan Teknologi.

Cao D, Li Y, Lu S, Wang J, Nan H, Li X, Shi D, Fang C, Zhai H, Yuan X, Anai T, Xia Z, Liu B, Kong F. 2015. GmCOL1aandGmCOL1bfintionasfloweingrepressor in sobeenn under longdday conditions [abstract]. Plant \& Cell Physiol.

Carpenter AC, Board JE. 1997. Branch yield components controlling soybean yield stability across plant populations. Crop Sci 37:885-91.

De Sousa PI, Egli DB, Bruening WP. 1997. Water stress during seed filling and leaf senescence in soybean. AgronJ 89:807-12.

Egli DB, Guffy RD, Leggett JE. 1985. Partitioning of assimilate between vegetative and reproductive growth in soybean. AgronJ 77:917-22.

El-Badawy MEM, Mehasen SAS. 2012. Correlation and path coefficient analysis for yield and yield components of soybean genotypes under different planting density. Asian J Crop Sci 4:150-8.

Hakim L, Suyamto, Paturohman E. 2014. G enetic variability, heritability and expected genetic advances of quantitative characters in $\mathrm{F} 2$ progenies of soybean crosses. IndonesiaJ A gric Sci 15(1):11-6.

Hidayat A, Mulyani A. 2002. Lahan kering untuk pertanian. Tekndog Pengddaan Lahan Keing Menju Petanian Prouluktif danRamahLingkungan Jakarta (ID ): Badan Penelitian dan Pengembangan Pertanian. p 1-34.

Kumagaia E, Sameshima R. 2014. G enotypic differences in soybean yield responses to increasing temperature in a cool climate are related to maturity group. Agricultural and Forest Meteorology 198-199: 265-72.

Kuswantoro H, Zen S. 2013. Performance of acid-tolerant soybean promising lines in two planting seasons. InterJ Biol 5(3):49-56.

Kuswantoro H, Zubaidah S, Sulisetijono. 2014. D ecreasing grain size caused declining grain yield of CpMMVresistant soybean lines grown in Ultisols. J Biol Sci 14:508-14.

Kuswantoro H. 2015. Response of Acid-Adaptive Soybean Genotypes Grown in Associated EntisolsInceptisols and Vertisols Soil Types. Inter J Soil Science 10:195-202.

Lee CD, Egli D B, Herbek JH. 2005. PredicingSaboen First Floneing Date Department of Plant and Sail Saienes Lexington (US): Cooperative Extention Service, University of Kentucky.
Lee S, Jun TH, Michel AP, Mian MAR. 2015. SNP markers linked to QTL conditioning plant height, lodging, and maturity in soybean. Euphytica203(3):521-32.

Liu B, Liu XB, Wang C, Li YS. Jin J, Herbert SJ. 2010. Soybean yield and yield component distribution across the main axis in response to light enrichment and shading under different densities. Plant Soil Environ 56 (8):384-92.

Liu Y, LiY, Reif JC, Mette MF, Liu Z, Liu B, Z hang S, Yan L, Chang R, Qiu L. 2013. Identification of quantitative trait loci underlying plant height and seed weight in soybean. The Plant Genome6:1-11.

Malik MFA, Ashraf M, Qureshi AS, Khan MR. 2011. Investigation and comparison of some morphological traits of the soybean populations using cluster analysis. Pakistan J Bot 43:1249-55.

Mulyani A, Syarwani M. 2013. Karakteristik dan potensi lahan sub optimal untuk pengembangan pertanian di Indonesia. In: Seminar Nasional Lahan Sub-optimal "Intensifikasi Pengelolaan Lahan Sub-optimal dalam Rangka Mendukung Kemandirian Pangan Nasional". Proceedings: 2021 September 2013; Palembang. ISBN 979-587501-9.

Na X, Jian B, Yao W, Wu C, Hou W, Jiang B, Bi Y, Han T. 2013. Cloning and functional analysis of the flowering gene $\mathrm{G} \mathrm{mSO} C 1$-like, a putative suppressor of overexpression $\mathrm{CO} 1 /$ Agamous-like 20 (SO C1/ AG L20) ortholog in soybean. Plant Cell Rep 32(8):1219-29.

Nugroho PA, Istianto. 2009. The characteristics and potency of Ultisols for developing rubber in part of Pulau Laut Area, South Kalimantan. Jurnal Penelitian Karet 27(2):51-64.

Sahay G, Sarma BK, D urai AA. 2005. Genetic variability and interrelationship in F2 segregating generation of soybean (Glyanemax (L) Merril) in mid-altitude of Meghalaya. Agric Sci D igest 25:107-10.

Valencia-Ramírez, R.A., Ligarreto-Moreno G.A. 2012. Phenotypic correlation and path analysis for yield in soybean (Glyaine max (L.) Merril). ACTA Agronómica 61(4):322-32.

Xia Z, Zhai H, Liu B, Kong F, Yuan X, Wu H, Cober ER, Harada K. 2012. Molecular identification of genes controlling flowering time, maturity, and photoperiod response in soybean. Plant Syst Evol 298 (7):1217-27.

Zhang J, Song Q, Cregan PB, Nelson RL, Wang X, Wu J, Jiang G L. 2015. G enome-wide association study for flowering time, maturity dates and plant height in early maturing soybean (Glyaine max) germplasm. BMC G enomics 16:217.

Zhang L, Allen Jr. LH, Vaughan MM, Hauser BA, Boote KJ. 2014. Solar ultraviolet radiation exclusion increases soybean internode lengths and plant height. Agr Forest Meteorol 184:170-8. 